\title{
PEMANFAATAN SAMPAH ILUNG MENJADI KERTAS MELALUI PROGRAM PENGEMBANGAN DESA LOK BAINTAN BERBASIS KOMUNIKATIF PARTISIPATIF
}

\author{
Muzahid Akbar Hayat ${ }^{1}$ dan Sanusi² \\ ${ }^{1}$ Magister Ilmu Komunikasi, Universitas Islam Kalimantan Muhammad Arsyad Al Banjari, Banjarmasin \\ Email: m.akbarhayat@gmail.com \\ ${ }^{2}$ Magister Ilmu Komunikasi, Universitas Islam Kalimantan Muhammad Arsyad Al Banjari, Banjarmasin \\ Email: sanusisanusi45@gmail.com
}

\begin{abstract}
ABSTRAK
Eceng Gondok merupakan tanaman gulma yang banyak tumbuh di sekitaran sungai wilayah Desa Lok Baintan Kalimantan Selatan. Banyaknya Eceng Gondok menimbulkan permasalahan diantaranya mengganggu sektor wisata pasar terapung dan transportasi sungai. Eceng Gondok merupakan jenis tumbuhan yang memiliki pertumbuhan sangat cepat. Sehingga perlu solusi nyata untuk mengatasi sampah Eceng Gondok. Dalam upaya mengurangi sampah Eceng Gondok adalah dengan melakukan pengelolaan pemanfaatan Eceng Gondok menjadi produk bernilai jual yaitu kertas melalui Program Pengembangan "Desa Sahabat Sampah”. Metode kegiatan dilalakukan dengan dialog, pendampingan (pelatihan kontinum realationship) dan pemberdayaan yang dirancang secara bersama serta bersifat keberlanjutan (sustainable). Penerapan pengembangan desa dilakukan berbasis komunikasi partisipatif yaitu dengan mengajak semua pihak (masyarakat) yang diundang untuk berpartisipasi dari proses komunikasi sampai dengan pengambilan keputusan.. Hasilnya Masyarakat mampu membuat kertas dan dikreasikan menjadi amplop dan kantong kertas.
\end{abstract}

Kata kunci: Komunikasi partisipatif, Pengelolaan, Sampah eceng gondok,

\section{PENDAHULUAN}

Banjarmasin merupakan kota yang dijuluki "kota seribu sungai" di mana didominasi oleh dataran rendah. Sebagian dari hamparan dataran rendah tersebut terutama di wilayah bagian barat merupakan dataran rawa. Pada wilayah ini vegetasi yang dominan adalah hutan rawa, hutan bakau dan jenis-jenis rumput rawa. Sungai-sungai besar berfungsi sebagai sarana transportasi yang penting bagi kehidupan ekonomi dan sosial masyarakat Kalimantan Selatan. Sungai Barito yang panjangnya sekitar 900 kilometer merupakan sungai terbesar yang mempunyai beberapa anak sungai.

Desa Lok Baintan merupakan Desa yang berada pada salah satu desa di Kecamatan Sungai Tabuk, Kabupaten Banjar Provinsi Kalimantan Selatan dimana aksesnya lebih banyak menggunakan sungai. Desa tersebut termasuk salah satu desa tertinggal berdasarkan Kepmen DPDTT-RI, nomor 126 tahun 2017, data No.12067, ID : 6303040010) di Kalimantan Selatan. Desa tersebut salah satu tujuan wisata yang terkenal dengan "Pasar Terapung". Jalan menuju tempat wisata dilalui dengan darat, tetapi tidak memadai, dan kebanyakan dilalui dengan memakai transportasi sungai dengan kapal kecil, yang disebut kelotok. Transportasi sungai ini paling disukai para wisatawan local, maupun manca negara. Klotok atau alat transportasi perahu lebih lama sampai tujuan karena berjalan dengan menghindari tanaman gulma tersebut.

Tanaman Enceng Gondok atau dalam bahasa Banjar di sebut "Ilung" adalah tumbuhan air yang tumbuh dirawa - rawa, sungai dan danau. Pertumbuhannya sangat cepat dan mampu menutupi seluruh permukaan sungai, Ilung dapat berkembang biak dengan dua cara yaitu dengan tunas dan biji. Ilung termasuk dalam kelompok gulma perairan yang memiliki kemampuan berkembang biak 
yang cepat, terutama di daerah tropis dan subtropis. Kehadiran Ilung sangat mencemaskan sehingga menjadi katagori sampah sungai, namun sampai sekarang ini belum ditemukan cara yang optimal untuk mengatasinya minimal dalam mengurangi sampah Ilung tersebut.

Masyarakat ekonomi kreatif adalah usaha yang dilakukan oleh masyarakat setempat untuk peningkatan penghasilan jati dirinya (Raimond, 2015). Komunikasi sebagai pendukung pembangunan dilaksanakan dalam model komunikasi horizontal, interaksi komunikasi dilakukan secara lebih demokratis. Kegiatan komunikasi bukan kegiatan memberi dan menerima melainkan "berbagi" dan "berdialog." Selama ini, keterlibatan masyarakat hanya dilihat dalam konteks yang sempit, artinya manusia cukup dipandang sebagai tenaga kasar untuk mengurangi biaya pembangunan sosial. Dengan kondisi ini, peran-peran serta masyarakat "terbatas" pada implementasi atau penerapan program, masyarakat tidak dikembangkan dayanya menjadi kreatif dari dalam dirinya dan harus menerima keputusan yang sudah diambil "pihak luar." Partisipasi menjadi bentuk yang pasif (Midgley, 1986 dalam Prijono dan Pranaka, 1996).

Sampah ilung yang ada disungai pernah hampir menutupi aliran sungai sehingga menyulitkan warga dan wisatawan menggunakan jalur transportasi sungai tersebut. Dampak yang signifikan adalah kurangnya wisatawan dan hal itu mengurangi pendapatan warga setempat khusunya penjual di pasar terapung.

Berdasarkan analisis situasi tersebut, bahwa perlu penyelesaian secara sistemik dan berkelanjutan yang dapat mengatasi sampah Ilung. Program Pengembangan Desa Mitra Kementrian Riset dan Teknologi Pendidikan Tingi melalui Pemberdayaan Masyarakat Peduli Lingkungan "Desa Sahabat Sampah". Program yang mengedepankan konsep ekonomi kreatif berbasis keberlanjutan bertujuan untuk memprioritaskankan pembersihan tanaman Ilung yang ada di sungai dengan memanfaatkan kembali menjadi produk bernilai jual tinggi menggunakan komunikasi partisipatif. Menurut Rahim (2004) komunikasi partisipatif adalah suatu proses komunikasi dimana terjadi komunikasi dua arah atau dialogis, sehingga menghasilkan suatu pemahaman yang sama terhadap pesan yang disampaikan.

Semua orang dapat berkomunikasi, namun tidak semua orang mampu untuk mengkomunikasikan sesuatu secara efektif hingga dapat memotivasi untuk menggerakan masyarakat untuk melakukan sesuatu yang membangun atau menciptakan sebuah inovasi. Kehadiran komunikasi untuk melakukan proses penyadaran pada masyarakat terhadap situasi kondisi lingkungan dengan melihat kondisi dan kemampuan dari masyarakat tersebut. Proses penyadaran membutuhkan banyak proses dialog yang merupakan proses komunikasi dua berkelanjutan sampai pada tahap menemukan suatu pemahaman dan pengertian hingga membentuk suatu kesadaran.

Komunikasi partisipatif yaitu dengan mengajak semua pihak yang diundang untuk berpartisipasi dalam proses komunikasi sampai dengan pengambilan keputusan. Komunikasi pendukung tersebut dilakukan secara lebih demokratis. Kegiatan komunikasi partisipatif adalah kegiatan yang bukan hanya memberi dan menerima namun lebih kepada "berbagi" dan "berdialog". Servaes (2005) mengungkapkan,

"Development communication is the sharing of knowledge aimed at reaching a consensus for action that takes into account the interest, needs and capacities of all concern'." 
Komunikasi pembangunan berarti berbagi pengetahuan yang mengarah pada pencapaian suatu konsensus untuk tindakan yang mempertimbangkan minat, kebutuhan-kebutuhan dan kapasitas dari semua yang terkait. Komunikasi telah menjadi bagian strategis yang perlu dicantumkan dalam setiap perencanaan pembangunan yang bersifat partisipatif.

Selama ini, keterlibatan masyarakat hanya cukup dipandang sebagai tenaga kasar untuk mengurangi biaya pembangunan sosial. Dengan kondisi ini, peran-peran serta masyarakat "terbatas" pada implementasi atau penerapan program, masyarakat tidak dikembangkan dayanya menjadi kreatif dari dalam dirinya dan harus menerima keputusan yang sudah diambil "pihak luar." Menurut Midgley dalam Prijono dan Pranaka (1996) Partisipasi menjadi bentuk yang pasif.

Kegiatan pemanfaatan Ilung menjadi kertas merupakan salah satu solusi dalam mengatasi maraknya sampah Ilung di sungai. Upaya ini dilakukan dalam rangka mengurangi sampah Ilung di sungai. Ilung mejadi bahan baku utama dalam pembuatan kertas, kartu nama, dan amplop. Kegiatan ini bertujuan untuk:

1. Membersihkan sungai dari sampah Ilung agar tidak mengganggu transportasi sungai;

2. Memanfaakan Ilung menjadi produk yang bermanfaat dan bernilai jual dengan memberdayakan masyarakat ekonomi kreatif melalui pemanfaatan Ilung.

\section{METODE PELAKSANAAN PKM}

Kegiatan ini dilakukan di Kantor Desa Lok Baintan kecamatan Sungai Tabuk Kabupaten Banjar, provinsi Kalimantan Selatan. Pengambilan dan pengumpulan data dilaksanakan sejak bulan September 2018 kemudian melakukan pelatihan dan pendidikan (Diklat) yang dilakukan di pada 08 April sampau dengan 13 April 2019.

Subjek dari kegiatan ini adalah para anggota Karang Taruna dan Anggota Pemberdayaan Kesejahteraan Keluarga (PKK) Desa Lok Baintan. Dukungan juga diberikan oleh lembaga pemerintahan yaitu Kepala Desa atau di sebut Pembakal serta tokoh masyarakat setempat. Jumlah subjek dari kegiatan ini ada 17 orang.

Data diperoleh dengan menggunakan teknik pengumpulan data melalui studi dokumentasi, pengamatan langsung di mana mekanisme kegiatan pengembangan Desa Lok Baintan dilakukan dengan metode pendekatan partisipatif yaitu dengan melakukan beberapa hal:

\section{Dialog publik}

Merupakan bagian dari komunikasi publik yaitu komunikasi antara sesorang pembicara dengan sejumlah besar orang (khalayak) yang tidak bisa dikenal satu persatu (Deddy Mulyana, 2007). Berangkat dari pertemuan dengan perwakilan masyarakat desa Lok Baintan juga kepala desa, karang taruna dan Ibu PKK (Pembinaan Kesejahteraan Keluarga) untuk menawarkan solusi dalam mengatasi permasalahan sampah Eceng Gondok.

\section{Focus Group Discussion (FGD)}

Diskusi group fokus adalah metode dengan melakukan diskusi kelompok terarah guna mengumpulkan data kualitatif serta memperoleh pengertian yang lebih seksama. FGD memiliki kelebihan diantaranya yaitu dapat mengembangkan kreativitas, dapat mengemukakan pendapat 
yang berbeda sehingga dapat memunculkan analisis data para persertanya (Ircham Mahfoedz dan Eko Suryani, 2008).

\section{Pelatihan kontinum relationship.}

Menurut Aroson et al (2014) dalam pelatihan kontinum relationship ada tiga komponen yang harus dilalui. Ketiga komponen itu adalah masukan (input), proses dan keluaran ( Output). Dari penjelasan tersebut maka dibuat dalam bentuk seperti dibawah ini :

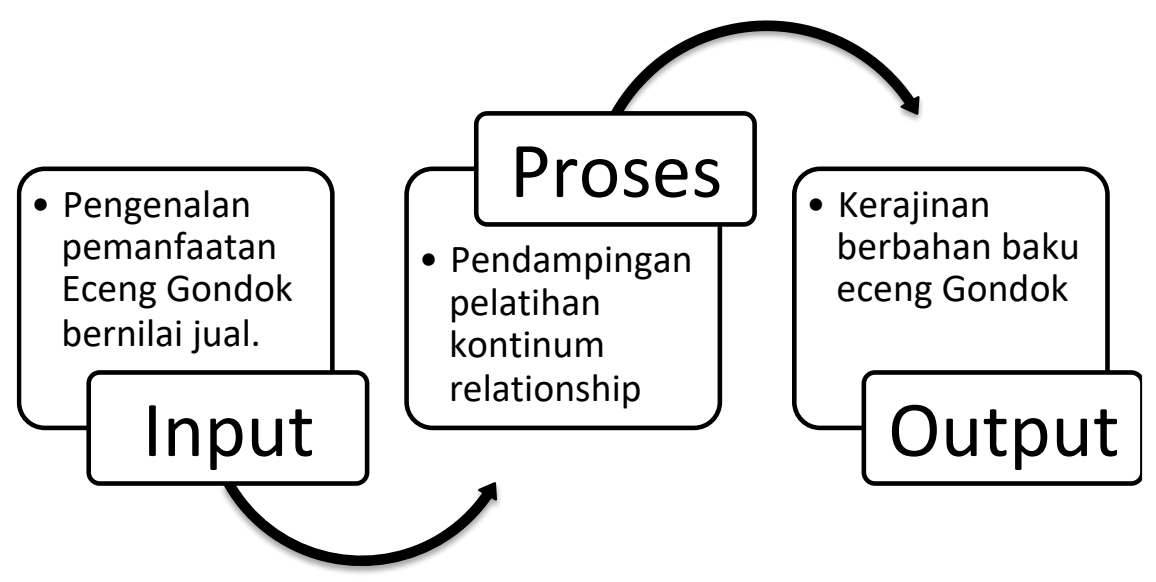

Gambar 1. Model Metode Pelatihan Kontinum Relationship.

Pelatihan kontinum relationship dilaksanakan dengan mengumpulkan pemuda karang taruna dan Ibu PKK di mana proses awal dilakukan dengan melakukan sosialisasi program, kemudian melakukan pendampingan dengan mengundang pelatih/narasumber/instruktur yaitu pakar daur ulang sampah/limbah untuk memberikan pelatihan daur ulang Ilung dan diakhiri dengan hasil produk nyata yaitu Ilung menjadi kertas.

\section{HASIL DAN PEMBAHASAN}

Kegiatan program pemanfaatan limbah Eceng gondok dimulai dengan melakukan dialog publik dengan Kepala Desa, Ketua Ibu PKK dan Ketua Karang Taruna. Dialog tersebut dilakukan untuk menentukan peserta peningkatan kemampuan dalam mengolah limbah Eceng Gondok. Penentuan Sumber Daya Manusia merupakan kunci utama dalam proram ini, maka seleksi awal sangat penting sehingga diharapkan dapat menghasilkan sumber daya manusia yang berkualitas serta mampu menjadi sumber informasi baru/instruktur baru dalam progam tersebut. Panitia mengundang 75\% dari jumlah penduduk di Desa Lok Baintan yang berjumlah 1.507 yaitu 1.130 orang. Dari undangan yang diberikan yang hadir berjumlah 40 orang dan dari syarat yang ditentukan hanya 17 orang yang bisa mengikuti program ini. 

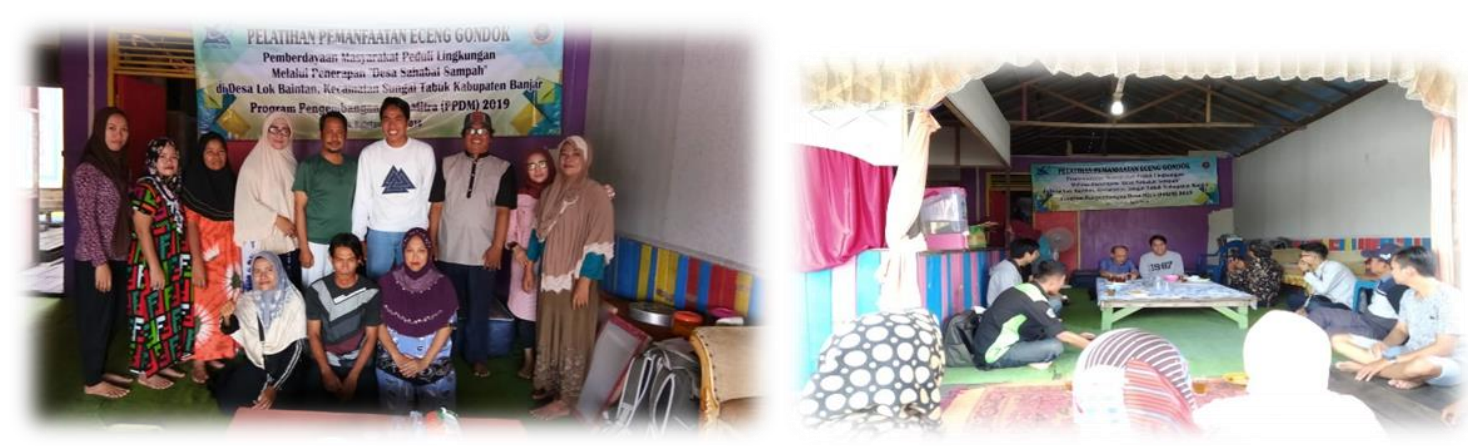

Gambar 2. Peserta Pendidikan dan Pelatihan.

Kegiatan pemanfaatan limbah Ilung berbasis keberlanjutan dilakukan oleh masyarakat sekitaran sungai dengan kreatifitas sebagai fundamentalnya.

\section{Masukan (Input)}

Merupakan proses pengenalan atau identifikasi dan sosialisasi program yang akan dilaksanakan di Desa Lok Baintan Kalimantan Selatan yang terdiri dari angota PKK dan Karang Taruna.

\section{Sosialisasi Program}

Melalui dialogis dengan kepala desa dan peserta dalam mengkatagorikan pelatihan sesuai dengan kebutuhan dan keadaan peserta. Serta menentukan kebutuhan akan teknologi tepat guna sehingga mampu memberikan solusi yang sesuai dari hulu hingg ke hilir.

Program dilaksanakan dengan pelatihan, pendampingan dan pemberdayaan hingga mampu menghasilkan nilai yang dapat meningkatkan perekonomian masyarakat setempat.

\section{Metode Pelatihan}

Dialog tukar pikiran dan sumbang saran yaitu proses dalam menentukan tempat, jadwal dan produk yang dibuat dan disepakati bersama; Ceramah, dengan menggundang pakar daur ulang sehingga menjadi inspirasi dan wawasan dalam berkreasi; dan Menciptakan sumber daya manusia berjiwa pengusaha yang memiliki kompetensi, kemampuan produksi dan mampu berdaya saing.

\section{Proses Pendampingan}

Tahap Pengenalan: Pengenalan alat-alat yang digunakan, pencacah, penghalus, pembentukan bubur kertas, pengeringan dan pencetakan; Pengenalan bagian eceng gondok yang digunakan serta hasil dari masing-masing bagian; dan Pengenalan bahan-bahan yang digunakan

\section{Tahap Pembuatan}

Membersihkan Ilung dari kotoran yang menempel; Setelah itu Ilung yang bersih di potong-potong (cacah) dan sebagian dijemur dan sebagian lagi langsung dihaluskan; 


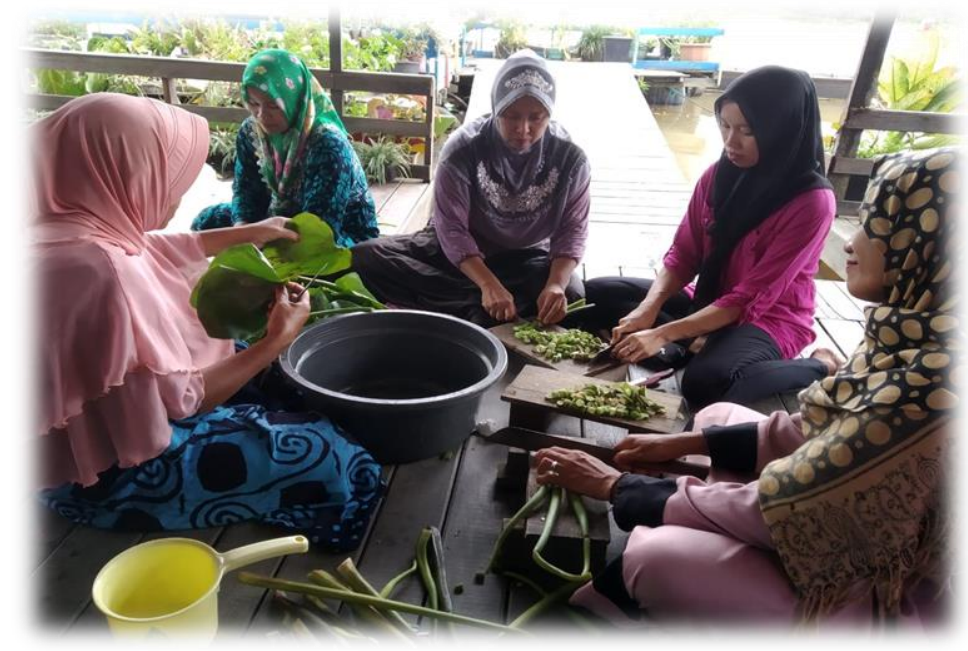

Gambar 3. Proeses Pencacahan Ilung

Eceng gondok kering ataupun basah di haluskan menjadi bubur; Bubur Eceng Gondok di cetak dalam dua ukuran A4 dan A3; Cetakan di jemur hingga selama 4 sampai 6 jam tergantung panas matahari.

\section{Gambar 4. Proeses Penjemuran Ilung}

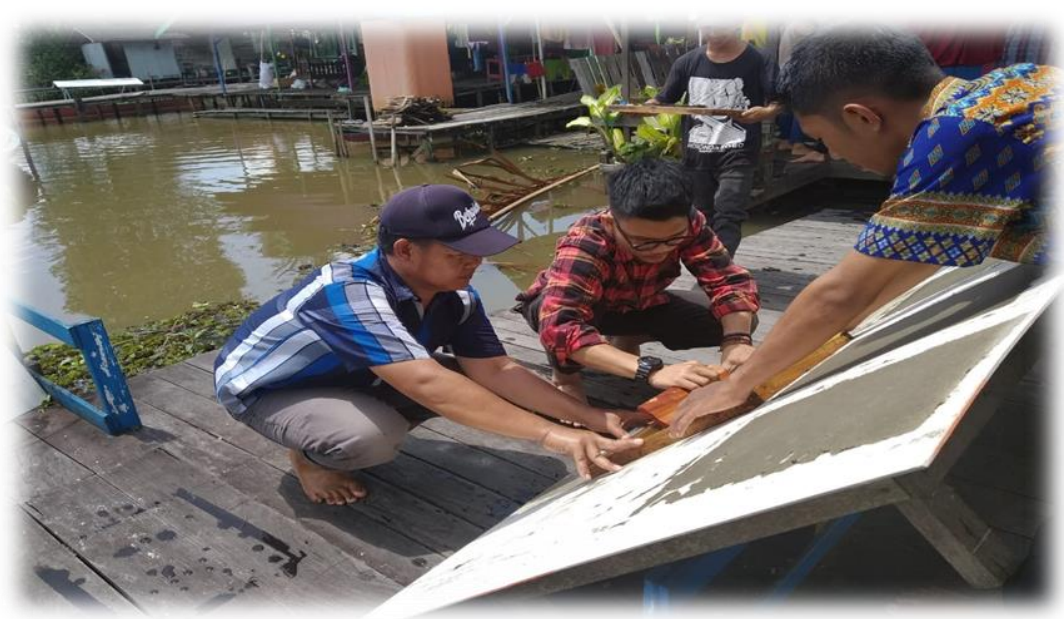

\section{Keluaran (Output)}

Adalah segala hal sesuatu yang dihasilkan dari produksi dari pelatihan di Desa Lok Baintan Kalimantan Selatan. Adapun produk pengolahan hasil sampah eceng gondok adalah kertas ukuran A4 dan A3, hasil kreatifitas seperti amplop, paper bag, dan produk lainnya yang mampu meningkatkan ekonomi kreatif masyarakat desa Lok Baintan Kalimantan Selatan. 


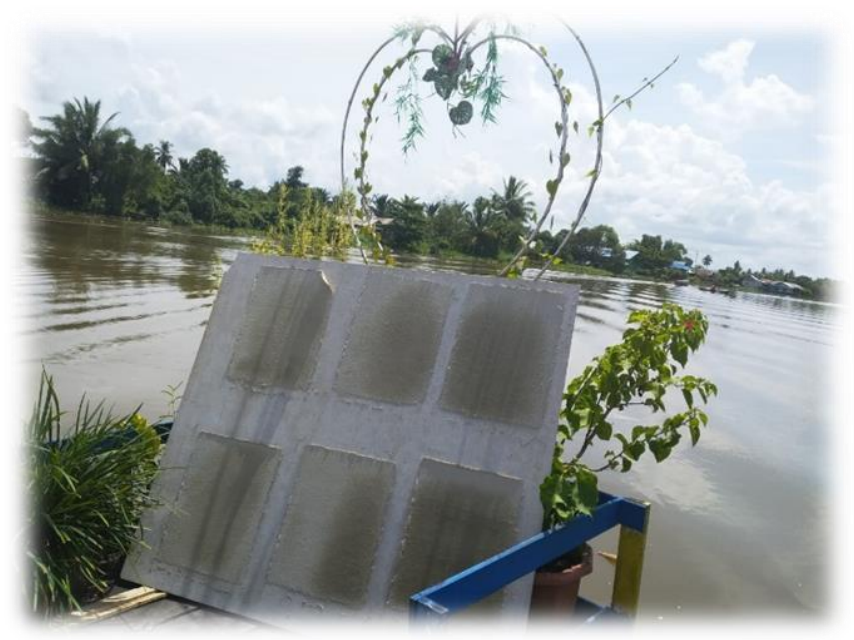

Gambar 5. Proeses Penjemuran Ilung

Berdasarkan hasil dari justifikasi dari tim dan mitra dalam menentukan permasalahan dapat dilihat pada tabel dibawah ini:

Tabel 1. Permasalahan dan Justifikasi

\begin{tabular}{|c|c|c|c|}
\hline No. & Permasalahan & Justifikasi & $\begin{array}{l}\text { Anggota Yang } \\
\text { Terlibat }\end{array}$ \\
\hline 1. & $\begin{array}{lr}\text { Rendahnya } & \text { pengetahuan } \\
\text { masyarakat } & \text { tentang } \\
\text { pemanfaatan } & \text { sampah eceng } \\
\text { gondok } & \end{array}$ & $\begin{array}{l}\text { 1. Sosialisasi tentang } \\
\text { pengelolahan sampah } \\
\text { eceng gondok untuk } \\
\text { kerajinan; } \\
\text { 2. Sosialisasi alat-alat yang } \\
\text { digunakan dalam proses } \\
\text { pengelolahan eceng } \\
\text { gondok; } \\
\text { 3. Pemetaan pemecahan } \\
\text { masalah; } \\
\text { 4. Membuat rencana } \\
\text { implementasi. }\end{array}$ & $\begin{array}{l}\text { Kepala Desa dan } 10 \\
\text { orang dari PKK dan } \\
\text { Karang Taruna }\end{array}$ \\
\hline 2. & $\begin{array}{l}\text { Tidak mengetahui } \\
\text { pengolahan eceng gondok }\end{array}$ & $\begin{array}{l}\text { 1. Pelatihan pemanfaatan } \\
\text { eceng gondok dari daun } \\
\text { hingga akar; } \\
\text { 2. Membuat rumusan } \\
\text { olahan dari eceng } \\
\text { gondok; } \\
\text { 3. Membuat kertas dari } \\
\text { eceng gondok. }\end{array}$ & $\begin{array}{l}\text { Kepala Desa dan } 10 \\
\text { orang dari PKK dan } \\
\text { Karang Taruna }\end{array}$ \\
\hline 3. & $\begin{array}{l}\text { Tidak mengetahui produk } \\
\text { yang bernilai jual }\end{array}$ & \begin{tabular}{lrr} 
1.Pelatihan & \multicolumn{2}{r}{ pembuatan } \\
kertas dari & eceng \\
gondok; & & \\
2.Pelatihan & membuat \\
amplop dan & kantong \\
kertas dari & eceng \\
gondok. & &
\end{tabular} & $\begin{array}{l}\text { Kepala Desa dan } 10 \\
\text { orang dari PKK dan } \\
\text { Karang Taruna }\end{array}$ \\
\hline
\end{tabular}

Sumber: Hasil Pengembangan Penelitian, 2019 
Kegiatan pengelolaan pemanfaatan eceng gondok menjadi kertas menjadi salah satu pilihan dalam mengembangkan usaha kecil masyarakat. Program pengembangan desa mampu meningkatkan pengetahuan tentang manfaat eceng gondok salah satu peserta yang merupakan kepala Desa mengungkapkan "Seumur-umur saya tinggal disini baru tahu kalau ilung (eceng gondok) bisa jadi kertas"; mampu meningkatkan keterampilan mengelola eceng gondok menjadi kertas, dan masyarakat terstimulus dalam meningkatkan kreatifitas merubah kertas eceng gondok menjadi kertas, amplop, kartu nama dan kantor kertas.
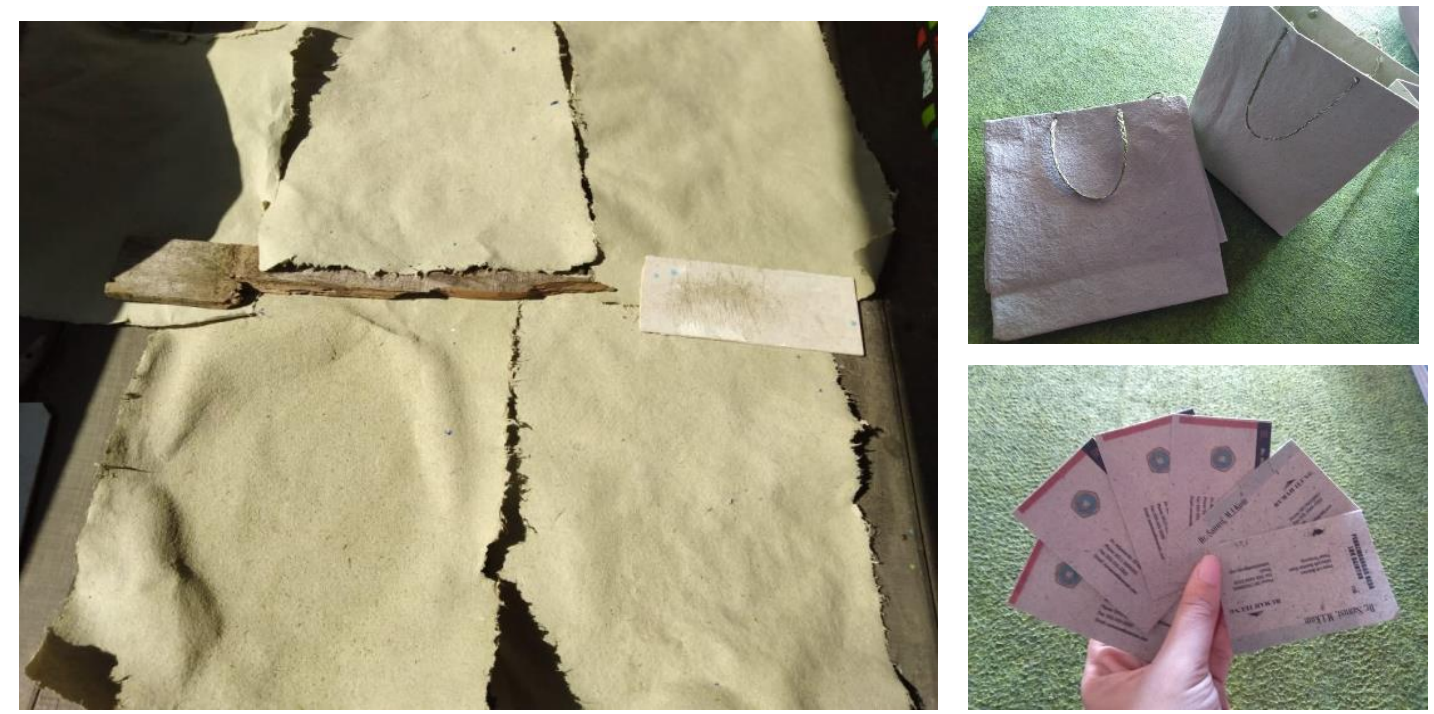

Gambar 6. Produk hasil kertas Ilung

\section{KESIMPULAN DAN SARAN}

Porgram Pengembangan Desa Lok Baintan melalui pemberdayaan masyarakat "Desa Sahabat Sampah" dengan memanfaatkan Ilung menjadi kertas berbasis Komunikasi partisipatif di nilai dapat mengurangi sampah ilung di sungai sekitar Desa Lok Baintan. Melibatkan semua pihak yaitu perserta kegiatan pengelolaan pemanfaatan ilung jadi kertas dari proses komunikasi sampai membuat keputusan menjadikan kegiatan ini berhasil dilakukan. Selain itu menumbuhkan rasa tanggung jawab bersama, kepercayaan dan rasa memiliki serta kesadaran tanggung jawab dalam upaya mengurangi sampah ilung.

Penggunaan Ilung sebagai bahan pokok pembuatan kertas selain dapat mengurangi sampah ilung juga dapat membuka peluang usaha baru yaitu dengan produk kertas yang bisa ditransformasikan menjadi kartu nama, amplop dan kantong kertas yang dapat di jual ke masyarakat.

Kegiatan ini memiliki manfaat langsung untuk masyarakat yang bermukim di bantaran sungai, danau dan rawa yang memiliki banyak Ilung. Untuk itu disarankan agar kegiatan ini bisa diduplikasi ke desa lain yang memiliki permasalahan yang sama.

\section{Ucapan Terima Kasih (Acknowledgement)}

Ucapan terima kasih disampaikan kepada Kementerian Riset, Teknologi, dan Pendidikan Tinggi Direktorat Ristek dan Pengabdian Kepada Masyarakat selaku penyandang dana hibah Program Pengembangan Desa Mitra (PPDM). Kepada Lembaga Penelitian dan Pengabdian Kepada 
Masyarakat Universitas Islam Kalimantan (Uniska) Muhammad Arsyad Al Banjari. Terima kasih kepada Bapak Sapriansyah, S.Ag. selaku Kepala Desa dan Ibu Herna Rusnawati selaku ketua PKK serta mahasiswa Uniska yang juga membantu dalam pelaksanaan kegiatan tersebut.

\section{REFERENSI}

Aronson, D, Bostic, R Huck, P Rownsed. R. (2014). Continum Relationship and Small Business Use. Of Market, J. Urban econ 55.46-67

Ircham Machfoedz dan Eko Suryani. (2008). Pendidikan Kesehatan Bagian dari Bagian dari Promosi Kesehatan. Yogyakarta: Fitramaya.

Mulyana, Deddy. (2007). Ilmu Komunikasi: Suatu Pengantar. Bandung : Remaja Rosdakarya.

Prijono Ony S. dan Pranaka, A.M.W. (penyunting). (1996). Pemberdayaan, Konsep, Kebijakan dan Implementasi. Jakarta: Centre For Strategic and International Studies.

Rahim SA. (2004). Participatory Development Communication as a Dialogical Process dalam White, SA. 2004. Participatory Communication Working for Change and Development. New Delhi: Sage Publication India Pvt Ltd.

Servaes J. (2005). Communication for Development: One World, Multiple Cultures. Cresskill, New Jersey (US): Second Printing. Hampton Press.

Sulistyowati F, Setyowati Y, Wuryantoro T. (2005). Komunikasi Pemberdayaan. Yogyakarta (ID): APMD. 